\title{
Differences in the Improvement of Students' Mathematical Reasoning Ability and Self-Confidence Between Metacognitive Approaches and Realistic Mathematical Approaches in MTS Negeri Balige
}

\author{
${ }^{1}$ Ady Putra, ${ }^{2}$ KMS. M. Amin Fauzi, ${ }^{3}$ Ahmad Landong \\ ${ }^{12}$ State University of Medan, North Sumatera, Indonesia
}

\begin{abstract}
This study aims to determine the differences in the improvement of students 'mathematical reasoning abilities and self-confidence taught by a metacognitive approach that is better than a realistic mathematics approach, as well as to analyze differences in the improvement of students' mathematical reasoning and self-confidence in terms of indicators. Data were obtained through tests of mathematical reasoning abilities consisting of students 'pre-test and post-test as well as a questionnaire to see students' self-confidence. Data were analyzed by independent test T-Test $\mathrm{N}$-Gain Score. Based on the results of the independent T-Test N-Gain test scores of students' mathematical reasoning abilities obtained a significance value $=0.008$ because of the sig level. smaller than 0.05 , so it is concluded that there is a difference in the increase in students' mathematical reasoning abilities with a metacognitive approach higher than the realistic mathematics approach. Furthermore, for self-confidence, the significance value $=0.000$ because of the sig level. smaller than 0.05 , it is concluded that there is a difference in the increase in students' self-confidence with a metacognitive approach higher than the realistic mathematics approach. Furthermore, for the research results, the difference in the increase in students' mathematical reasoning and self-confidence in terms of the indicators is that there is a significant difference in the increase in mathematical reasoning abilities in indicator 1 and indicator 2 which are taught with a metacognitive approach which is higher than students who are taught with a realistic mathematics approach and for indicators 3 and 4 . there is no significant difference in the increase in mathematical reasoning abilities. For self-confidence, there is no significant difference in the increase in mathematical reasoning skills in indicator 1 and indicator 2 who are taught with a metacognitive approach and students who are taught with a realistic mathematics approach and there is a significant difference in the increase in self-confidence in indicator 3 , indicator 4 , and indicator 5 who are taught with the metacognitive approach is better than students who are taught with a realistic mathematics approach.
\end{abstract}

Keywords: Metacognitive Approach, Realistic Mathematical Approach, Mathematical Reasoning Ability, SelfConfidence

DOI: $10.7176 / \mathrm{JEP} / 11-36-15$

Publication date: December $31^{\text {st }} 2020$

\section{Introduction}

Mathematics needs to be taught to students because, it is always used in all aspects of life, all fields of study require appropriate mathematical skills, is a strong, concise, and clear communication tool, can be used to present information in various ways, improves logical thinking skills, accuracy and awareness of deficiencies and providing satisfaction with efforts to solve challenging problems (Abdurrahman in Lubis and Surya, 2016)

Through good mathematics education, students can indeed obtain various kinds of provisions in facing challenges in the global era. In the 2013 curriculum itself, the use of technology in learning became something that was highly recommended. The learning process in the 2013 curriculum requires students to participate actively and provide sufficient space for students' creativity, interests, and talents (Fitri, Syahputra, \& Syahputra, 2019).

The Indonesian government has made various efforts to improve the quality of teaching and improve student mathematics learning outcomes, because mathematics is a very important science in every level of education pursued by every Indonesian citizen. The government's efforts include developing curricula, providing training to teachers, completing educational infrastructure and even improving teacher welfare. Along with the development of the internet, learning strategies have shifted and various information and communication technology-based learning strategies have emerged, from e-learning models, smart classroom technology, virtual classrooms, belded learning, etc. (Fitri \& Zahari, 2019).

Mathematical reasoning ability is a skill or skill that is very important in achieving mathematics learning goals, because reasoning skills will hone students' reasoning power towards patterns and properties, perform mathematical manipulation in making generalizations, compiling evidence, or explaining mathematical ideas and statements. Mathematical reasoning that must be achieved by students as stated by Purba, Surya, Manullang and Asmin (2018) As for the indicators that show the existence of reasoning in mathematics among others: (1) present the mathematical statements orally, written, pictures and diagrams, (2) ask the alleged, (3) conducting 
mathematical manipulation, (4) draw conclusions, compiling evidence, provide a reason or evidence against some of the solutions, (5) draw conclusions from the statements, (6) checking the validity of an argument, (7) specify the nature of the symptom pattern or mathematically to make generalizations.

Meanwhile, according to Rizqi and Surya (2017): reasoning or reasoning indicators that must be achieved by the students based on the regulation of Dikdasmen No.506/C/PP/2004: (1) the ability to present mathematic statement verbally, written, picture, diagram, (2) the ability to present validity, (3) the ability to do mathematic manipulation, (4) the ability to arrange the proof, giving reason/proof to the truth solution, (5) the ability to make a conclution of statement, (6) checking the error of argument, (7) finding the pattern or character from mathematical shymton to make a generalization.

Based on the description, the indicators of mathematical reasoning for students in this study are: 1. the ability to present oral, written, pictures and diagrams statements; 2 . the ability to submit conjectures; 3 . ability to manipulate mathematics; 4 . The ability to draw conclusions, compile evidence, provide reasons or evidence for several solutions; 5 . Ability to draw conclusions from statements; 6 . the ability to check the validity of an argument; 7. the ability to find patterns or properties of mathematical symptoms to make generalizations

Mathematical reasoning skills ensure that each student learns more and is involved in the learning process. However, in addition to having good reasoning, students 'self-confidence also greatly affects students' memory and memory of the material being studied. Self confidence in each student is an attitude of convincing students' ability and self-assessment (judgment) in carrying out tasks and choosing a more effective approach in solving the problems at hand. This includes confidence in his ability to cope with an increasingly challenging environment and confidence in his own decisions or opinions. By paying attention to students' self confidence will help teachers accelerate the learning process because it can make learning more meaningful and permanent.

According to Martyanti (in Nurkholifah, Toheri and Winarso, 2018) self confidence is the belief that a student is able to cope with a problem in the best situation and can provide something fun for others. This opinion shows that self-confidence is a student's belief in all aspects of his strengths and that belief makes him feel able to achieve various goals in the mathematics learning process and also to achieve various goals in living life in the future.

Meanwhile Lautser (in Surya, Putri and Mukhtar, 2017) said: there are several characteristics to assess the confidence of individuals, such as: believe in their own abilities, to act independently in making decisions, have a positive self-concept, and the courage to express opinions. According to Pane, Syahputra and Mulyono (2018) Self-confidence is defined as a self-confidence that each individual has in his life, and how the individual views himself as a whole by referring to self-concept

Related to mathematics, Margono (Martyanti, 2013) revealed that students' self-confidence in learning mathematics can be divided into three aspects, namely: (1) belief in understanding and self-awareness of their mathematical abilities, (2) the ability to realistically determine the goals to be achieved and arranging actions in an effort to achieve goals, and (3) belief in mathematics itself. Based on this description, the indicators of students' self confidence in this study are: 1. Confidence in one's own abilities. 2. Optimistic. 3. Objective. 4. Responsible, and 5. Rational, and realistic.

Nasution and Surya (2017) say that the learning model that allows students to develop thinking skills (reasoning, communication, and connection) in solving problems is a metacognitive approach. Nasution and Surya (2017) also say that metacognitive is a person's ability to control the learning process, starting from the planning stage, choosing the right strategy according to the problem at hand, then monitoring progress in learning and simultaneously correcting if there are errors that occur while understanding the concept, analyze the effectiveness of the chosen strategy.

The metacognitive approach can be used to analyze concepts that students have comprehensively understood. This idea is based on Ausubel's learning theory which emphasizes that teachers know the concepts that students already have so that meaningful learning can take place. In meaningful learning, new knowledge must be linked to relevant concepts that already exist in students' cognitive structures. If there are no relevant concepts in the cognitive structure, the new knowledge that has been learned is just memorization.

According to Murni (in Hutauruk, 2016), teacher activities in fostering student metacognition in mathematics learning can be carried out in the following ways: 1 . The teacher as a facilitator who supports and helps students to control their thinking processes and activities, choose problem-solving strategies, do self-evaluation, do selfreflection, and don't give up easily. 2. The teacher and the students check the correctness of the students' answers. 3. The teacher gives awards 4 . The teacher asks students to write diary notes about their experiences following the lesson 5. The teacher models metacognitive behavior in learning. Furthermore, student activities can be carried out in the following ways: 1. Controlling the process of thinking itself about knowledge and problem solving strategies 2. Stating the thinking process in discussions or self-representation of the problems at hand 3. Making plans for learning activities such as managing time, teaching materials, troubleshooting procedures and so on. 4 . Make daily notes 5 . Evaluate the success of learning activities.

To help students do reasoning in solving math problems, the syntax of a metacognitive approach that can be used is: 
1. Focus on the problem.

2. Decide on how to solve the problem.

3. Implement decisions to solve problems.

4. Interpret the results of the problem.

5. Evaluation of the problem.

In addition to using a metacognitive approach to measure students' mathematical reasoning abilities and selfconfidence, another approach that can also be used is the realistic mathematics approach (PMR). According to Hadi (in Hernawati 2016) states that the PMR concept is in line with the need to improve mathematics education in Indonesia which is dominated by the problem of how to improve students' understanding of mathematics and develop the reasoning power of each student. Meanwhile, according to Kuiper \& Knuver (in Mustamin, 2017): Several preliminary studies in several countries show that learning using a realistic approach, at least can make: a. Mathematics is more interesting, relevant, and meaningful, less formal and less abstract, b. Considering the level of ability of students, c. Emphasize learning mathematics on "learning by doing". d. Facilitating solving mathematical problems without using standard solutions (algorithms). e. Using context as a starting point for learning mathematics.

According to Fauzi (in Amin, 2017) the steps in the mathematics learning process with the PMR approach are as follows: a. The first step: understanding contextual problems, where the teacher provides contextual problems in everyday life and asks students to understand these problems. $b$. The second step: explaining the contextual problem, that is, if students experience difficulties in understanding the problem, then the teacher explains the situation and condition of the problem by providing instructions or in the form of suggestions as needed, limited to certain parts of the problem that have not been understood. c. The third step: solving contextual problems, where students individually solve contextual problems in their own way. Different ways of solving and answering problems are preferred. By using worksheets, students work on questions. The teacher motivates students to solve problems in their own way. $d$. The fourth step: comparing and discussing answers, the teacher provides time and opportunity for students to compare and discuss answers to problems in groups. Students are trained to bring out the ideas they have in relation to student interactions in the learning process to optimize learning. e. The fifth step: concluding, that is, the teacher gives students the opportunity to draw conclusions about a concept or procedure.

Based on the background description, researchers are interested in conducting research to reveal whether there is a difference in the improvement of students' mathematical reasoning abilities and self-confidence between the metacognitive approach and the realistic mathematics approach of MTs students.

\section{Methods}

This study took two parallel classes randomly by applying different learning, namely class VIII-A was designated as experimental class A and class VIII-B was designated as experimental class B. Experiment class A was treated by applying the Metacognitive approach and experimental class B was treated with apply the PMR approach. The experimental design in this study can be described as follows:

Table 1. Research Design

Information :

\begin{tabular}{|c|c|c|c|}
\hline Class & Pre Test & Treatment & Post Test \\
\hline Experiment (A) & $\mathrm{T}_{1}$ & $\mathrm{X}_{1}$ & $\mathrm{~T}_{2}$ \\
\hline Experiment (B) & $\mathrm{T}_{1}$ & $\mathrm{X}_{2}$ & $\mathrm{~T}_{2}$ \\
\hline
\end{tabular}

$\mathrm{X} 1$ = Treatment Metacognitive approach

$\mathrm{X} 2$ = Treatment PMR approach

$\mathrm{T} 1=$ Pre test

$\mathrm{T} 2=$ Post test

The The population in this study were all students of class VIII MTS Negeri Balige, totaling 60 students who were divided into 2 classes. Sampling in this study is to use total sampling. Total sampling is a research sampling technique where the number of samples is the same as the population. The reason for this total sampling was because the total population used as the research sample was 60 students. Which consists of 2 classes, namely class VIII-A and class VIII-B. Then class VIII-A was designated as experimental class A and class VIII-B was designated as experimental class $\mathrm{B}$, each class totaling 30 students

The research instrument used was a test of mathematical reasoning abilities consisting of students 'pre-test and post-test as well as a questionnaire to see students' self-confidence. The test is in the form of essay questions with 4 questions for the pre-test and 4 questions for the post-test. The self-confidence questionnaire was given to students in each experimental class after learning with the metacognitive approach and the PMR approach. In this study consisted of 30 statements with four answer choices, namely SS (Strongly Agree), S (Agree), TS (Disagree) and STS (Strongly Disagree). This study uses the Independent T-Test. Data processing begins with testing the statistical requirements needed as a basis for testing hypotheses, including the data normality test and the variance 
homogeneity test. Furthermore, the Independent T-Test is carried out. All statistical calculations use the help of the SPSS 22 computer program.

\section{Result And Discussion}

Students' mathematical reasoning abilities were obtained from the results of the pretest and posttest given to the experimental class A and the experimental class B. The pretest was given before the treatment or implementation of learning and the posttest was given after the treatment or implementation of the learning. The results of the students' mathematical reasoning ability test can be seen in Table 2 below :

Table 2. Average Results of the Pretest and Posttest of Mathematical Reasoning Ability in the Two Experiment Classes

\begin{tabular}{|c|c|c|c|c|}
\hline \multirow{3}{*}{ Statistics } & \multicolumn{4}{|c|}{ Learning } \\
\hline & \multicolumn{2}{|c|}{ Experiment class A PM } & \multicolumn{2}{|c|}{ Experiment class B PMR } \\
\hline & Pre Test & Pos Test & Pre Test & Pos Test \\
\hline Average & 51,33 & 87,33 & 50.50 & 82,33 \\
\hline
\end{tabular}

Based on table 2 above, it shows that the results of the pre-test and post-test in each class have an increase where in the experimental class A the average post-test results is higher than the average pretest results, namely 87.33 $>51.33$. This shows that there is an increase in the average test results of students' mathematical reasoning abilities in experimental class A by 36. Likewise in experimental class B that the average post-test results are higher than the average pretest results, namely $82.33>50.50$. This also shows that there is an increase in the average test results of students' mathematical reasoning abilities in experimental class B by 31.83 . Based on this average increase, it can be seen that the increase in the average increase in experimental class $\mathrm{A}$ is higher than the increase in the average increase in experimental class B.

Independent T-Test N-Gain Score was used to test the hypothesis, students 'mathematical reasoning ability to answer whether there was a significant difference between the metacognitive approach and the realistic mathematics approach to the improvement of students' mathematical reasoning abilities. First, the difference between the total N-Gain score for experiment class A and experiment B will be tested, which is summarized in table 3 below:

Table 3. Independent T Test Results N-Gain Test Data Score of Mathematical Reasoning Ability

\section{Independent Samples Test}

\begin{tabular}{|c|c|c|c|c|c|c|c|c|c|c|}
\hline & \multicolumn{2}{|c|}{$\begin{array}{l}\text { Levene's } \\
\text { Test for } \\
\text { Equality of } \\
\text { Variances }\end{array}$} & \multicolumn{7}{|c|}{ t-test for Equality of Means } \\
\hline & & \multirow[t]{2}{*}{$\mathrm{F}$} & \multirow[t]{2}{*}{ Sig. } & \multirow[t]{2}{*}{$\mathrm{t}$} & \multirow[t]{2}{*}{$\mathrm{df}$} & \multirow[t]{2}{*}{$\begin{array}{l}\text { Sig. } \\
(2- \\
\text { tailed) }\end{array}$} & \multirow[t]{2}{*}{$\begin{array}{c}\text { Mean } \\
\text { Difference }\end{array}$} & \multirow[t]{2}{*}{$\begin{array}{l}\text { Std. Error } \\
\text { Difference }\end{array}$} & \multicolumn{2}{|c|}{$\begin{array}{l}95 \% \text { Confidence } \\
\text { Interval of the } \\
\text { Difference }\end{array}$} \\
\hline & & & & & & & & & Lower & Upper \\
\hline \multirow{2}{*}{$\begin{array}{l}\mathrm{N} \quad \text { Gain } \\
\text { IndikatorTotal }\end{array}$} & $\begin{array}{l}\text { Equal } \\
\text { variances } \\
\text { assumed }\end{array}$ & ,924 & ,340 & 2,755 & 58 & ,008 & ,08767 & ,03182 & ,02398 & , 15135 \\
\hline & \begin{tabular}{|l} 
Equal \\
variances \\
not \\
assumed \\
\end{tabular} & & & 2,755 & 57,35 & ,008 &, 08767 & ,03182 & ,02396 & , 15137 \\
\hline
\end{tabular}

Based on the data in the table above, it is found that the sig 2 tailed value is smaller, which is equal to 0.008 $<0.005$, which means that there is a significant (real) difference in $\mathrm{N}-$ Gain scores between experimental class A and experiment B. So based on the tests that have been carried out it can be concluded that $\mathrm{H}_{0}$ is rejected. and $\mathrm{H}_{1}$ is accepted, namely there is a difference in the increase in students' mathematical reasoning abilities between students who get a higher metacognitive approach than the realistic mathematics approach. Then the independent T-Test N-Gain Score test will be carried out based on each indicator of mathematical reasoning. Independent TTest N-Gain The score for each indicator is obtained by comparing the N-Gain score of each indicator in each class. Then it will be concluded that there is a significant difference between the reasoning abilities of the two experimental classes. In Table 4, the following is a summary of the scores from the Independent T-Test N-Gain test scores for the mathematical reasoning ability of each indicator. 
Table 4.Independent T Test Results N-Gain Score Per Data Indicator of Mathematical Reasoning Ability Independent Samples Test

\begin{tabular}{|c|c|c|c|c|c|c|c|c|c|c|}
\hline & \multicolumn{2}{|c|}{$\begin{array}{l}\text { Levene's Test } \\
\text { for Equality } \\
\text { of Variances }\end{array}$} & \multicolumn{7}{|c|}{ t-test for Equality of Means } \\
\hline & & \multirow[t]{2}{*}{$\mathrm{F}$} & \multirow[t]{2}{*}{ Sig. } & \multirow[t]{2}{*}{$\mathrm{t}$} & \multirow[t]{2}{*}{ df } & \multirow{2}{*}{$\begin{array}{l}\text { Sig. } \\
(2- \\
\text { tailed })\end{array}$} & \multirow[t]{2}{*}{$\begin{array}{c}\text { Mean } \\
\text { Difference }\end{array}$} & \multirow[t]{2}{*}{$\begin{array}{l}\text { Std. Error } \\
\text { Difference }\end{array}$} & \multicolumn{2}{|c|}{$\begin{array}{l}95 \% \text { Confidence } \\
\text { Interval of the } \\
\text { Difference }\end{array}$} \\
\hline & & & & & & & & & Lower & Upper \\
\hline \multirow[t]{2}{*}{$\begin{array}{l}\mathrm{N} \text { Gain } \\
\text { Indikator } \\
1\end{array}$} & \begin{tabular}{|l} 
Equal \\
variances \\
assumed \\
\end{tabular} & 065 & ,799 & 2,288 & 58 & ,026 & , 10200 & ,04459 &, 01274 & , 19126 \\
\hline & $\begin{array}{l}\text { Equal } \\
\text { variances } \\
\text { not } \\
\text { assumed }\end{array}$ & & & 2,288 & 57,531 & ,026 & , 10200 & 04459 & 01273 & , 19127 \\
\hline \multirow[t]{2}{*}{$\begin{array}{l}\mathrm{N} \text { Gain } \\
\text { Indikator } \\
2\end{array}$} & \begin{tabular}{|l} 
Equal \\
variances \\
assumed \\
\end{tabular} & 3,545 & ,065 & 2,355 & 58 &, 022 & , 11667 & ,04953 &, 01752 & ,21582 \\
\hline & $\begin{array}{l}\text { Equal } \\
\text { variances } \\
\text { not } \\
\text { assumed }\end{array}$ & & & 2,355 & 54,252 &, 022 & , 11667 & 04953 &, 01737 & ,21596 \\
\hline \multirow[t]{2}{*}{$\begin{array}{l}\mathrm{N} \text { Gain } \\
\text { Indikator } \\
3\end{array}$} & $\begin{array}{l}\text { Equal } \\
\text { variances } \\
\text { assumed } \\
\end{array}$ & 1,615 & ,209 & 1,939 & 58 & 057 & ,09600 &, 04950 &,- 0039 & ,19509 \\
\hline & $\begin{array}{l}\text { Equal } \\
\text { variances } \\
\text { not } \\
\text { assumed }\end{array}$ & & & 1,939 & 57,707 & ,058 & ,09600 &, 04950 &,- 00318 & , 19518 \\
\hline \multirow[t]{2}{*}{$\begin{array}{l}\mathrm{N} \text { Gain } \\
\text { Indikator } \\
4\end{array}$} & $\begin{array}{l}\text { Equal } \\
\text { variances } \\
\text { assumed } \\
\end{array}$ & 1,222 & ,274 & 1,902 & 58 & ,062 & ,09167 &, 04820 &,- 00481 &, 18814 \\
\hline & $\begin{array}{l}\text { Equal } \\
\text { variances } \\
\text { not } \\
\text { assumed }\end{array}$ & & & 1,902 & 53,736 &, 063 & 09167 &, 04820 &,- 00497 &, 18831 \\
\hline
\end{tabular}

From Table 4 above it can be seen that the Significance value of indicator 1 is $0.026<0.05$ which concludes that there is a significant difference (real) then refers to the N-Gain score indicator 1 which shows the N-Gain score for Experiment Class A of 0, 72 higher than the N-Gain score of Experimental Class B of 0.64, the independent $\mathrm{T}$ Test results in table 3 above conclude that there is a significant difference in the increase in mathematical reasoning abilities on the indicators of drawing logical conclusions from students who are taught with a metacognitive approach higher than students who taught with a realistic mathematical approach.

In indicator 2 the significance value is $0.022<0.05$ which also concludes that there is a significant difference (real) then refers to the $\mathrm{N}$-Gain score indicator 2 which shows the $\mathrm{N}$-Gain score for Experiment Class A is 0.735 higher than the N-Gain score Experiment Class B is 0.62, the results of the independent T Test in Table 4 above conclude that there is a significant difference in the increase in mathematical reasoning ability on indicators of providing an explanation for existing models, facts, properties and relationships or patterns, students who are taught with a more metacognitive approach. higher than students who were taught with a realistic mathematics approach.

In indicator 3 the significance value is $0.057>0.05$ which concludes that there is no significant difference (real) then refers to the N-Gain score indicator 3 which shows the N-Gain score for Experiment Class A is 0.827 higher than the N-Gain score Experiment Class B is 0.73 but the results of the independent $\mathrm{T}$ Test in table 4 above conclude that there is no significant difference in the increase in mathematical reasoning abilities on indicators of making assumptions and compiling evidence, students who are taught with the metacognitive approach give the same increase as students who are taught with the approach high category realistic mathematics.

In indicator 4 the significance value is $0.062>0.05$ which concludes that there is no significant difference 
(real) then refers to the N-Gain score indicator 4 which shows the N-Gain score for Experiment Class A is 0.687 higher than the N-Gain score Experiment Class B is 0.60 but the results of the independent $\mathrm{T}$ Test in table 4 above conclude that there is no significant difference in the increase in mathematical reasoning abilities on indicators using relationship patterns to analyze situations, or to make analogies or generalizations, students who are taught with a metacognitive approach give an increase. the same as students who were taught with a realistic mathematics approach in the moderate category.

Table 5. Summary of Differences in the Improvement of Mathematical Reasoning Ability for Each Indicator

\begin{tabular}{|l|c|c|c|c|}
\hline \multirow{2}{*}{\multicolumn{1}{c|}{ Class }} & \multicolumn{4}{|c|}{ N-Gain Reasoning Ability Score } \\
\cline { 2 - 5 } & Indicator 1 & Indicator 2 & Indicator 3 & Indicator 4 \\
\hline Experiment A & 0,720 & 0,735 & 0,827 & 0,687 \\
\hline Experiment B & 0,64 & 0,62 & 0,73 & 0,60 \\
\hline Sig 2 tailed & 0,026 & 0,22 & 0,57 & 0,62 \\
\hline
\end{tabular}

Furthermore, the results of the student's Self Confidence analysis will be presented. The results of students 'Self Confidence were obtained from the results of giving the students' Self Confidence scale before and after the learning process took place in the experimental class A and the experimental class B. The results of the calculation of the student's Self Confidence scale before and after the learning process took place for both classes. . The results of the descriptive analysis of student Self Confidence data are presented in Table 6 below:

Table 6. Description of the results of the Pre-test Self Confidence students' mathematical reasoning ability by class

\begin{tabular}{|c|c|c|}
\hline \multirow{2}{*}{ Statistics } & \multicolumn{2}{|c|}{ Experiment Class } \\
\cline { 2 - 3 } & (A) PM & (B) PMR \\
\hline $\mathbf{N}$ & 30 & 30 \\
\hline Average & 50,86 & 51.25 \\
\hline
\end{tabular}

Independent T-Test N-Gain Score was used to test the hypothesis, students 'Self Confidence to answer whether there was a significant difference between the metacognitive approach and the realistic mathematics approach to the change in students' Self Confidence. First, the difference between the total N-Gain score for experimental class A and experiment B will be tested, which is summarized in table 7. below.

Table 7.Independent T Test Results N-Gain Student Self Confidence Questionnaire

Independent Samples Test

\begin{tabular}{|c|c|c|c|c|c|c|c|c|c|c|}
\hline & \multicolumn{2}{|c|}{$\begin{array}{l}\text { Levene's } \\
\text { Test for } \\
\text { Equality of } \\
\text { Variances }\end{array}$} & \multicolumn{7}{|c|}{ t-test for Equality of Means } \\
\hline & & \multirow[t]{2}{*}{$\mathrm{F}$} & \multirow[t]{2}{*}{ Sig. } & \multirow[t]{2}{*}{$\mathrm{t}$} & \multirow[t]{2}{*}{ df } & \multirow{2}{*}{$\begin{array}{l}\text { Sig. } \\
(2- \\
\text { tailed })\end{array}$} & \multirow[t]{2}{*}{$\begin{array}{c}\text { Mean } \\
\text { Difference }\end{array}$} & \multirow[t]{2}{*}{$\begin{array}{l}\text { Std. Error } \\
\text { Difference }\end{array}$} & \multicolumn{2}{|c|}{$\begin{array}{l}95 \% \text { Confidence } \\
\text { Interval of the } \\
\text { Difference }\end{array}$} \\
\hline & & & & & & & & & Lower & Upper \\
\hline \multirow{2}{*}{$\begin{array}{l}\mathrm{N} \quad \text { Gain } \\
\text { IndikatorTotal }\end{array}$} & $\begin{array}{l}\text { Equal } \\
\text { variances } \\
\text { assumed }\end{array}$ & ,004 & ,951 & 4,534 & 58 & ,000 & ,10733 &, 02368 & ,05994 &, 15472 \\
\hline & $\begin{array}{l}\text { Equal } \\
\text { variances } \\
\text { not } \\
\text { assumed }\end{array}$ & & & 4,534 & 57,79 & 000 &, 10733 &, 02368 & ,05994 & 15473 \\
\hline
\end{tabular}

Based on the data in table 6 above, it is found that the sig 2 tailed value is smaller, which is equal to $0.000<$ 0.005 , which means that there is a significant (real) difference in N-Gain scores between experimental class A and experiment $\mathrm{B}$. rejected and $\mathrm{H}_{1}$ accepted, namely there is a difference in the increase in students' mathematical reasoning abilities between students who get the metacognitive approach better than the realistic mathematics approach. Then the independent T-Test N-Gain Score test will be carried out based on each Self Confidence indicator. Independent T-Test N-Gain The score for each indicator is obtained by comparing the N-Gain score of each indicator in each class, then it will be concluded that there is a significant difference between the Self Confidence of the two experimental classes. In Table 8. The following is a summary of the scores of the Independent T-Test, N-Gain, Self-Confidence scores for each indicator. 
Table 8. Summary of Independent T-Test Results N-Gain Score Self-Confidence for Each Indicator Independent Samples Test

\begin{tabular}{|c|c|c|c|c|c|c|c|c|c|c|}
\hline & \multicolumn{2}{|c|}{$\begin{array}{l}\text { Levene's Test } \\
\text { for Equality } \\
\text { of Variances }\end{array}$} & \multicolumn{7}{|c|}{ t-test for Equality of Means } \\
\hline & & \multirow[t]{2}{*}{$\mathrm{F}$} & \multirow[t]{2}{*}{ Sig. } & \multirow[t]{2}{*}{$\mathrm{t}$} & \multirow[t]{2}{*}{ df } & \multirow[t]{2}{*}{$\begin{array}{l}\text { Sig. } \\
(2- \\
\text { tailed })\end{array}$} & \multirow[t]{2}{*}{$\begin{array}{c}\text { Mean } \\
\text { Difference }\end{array}$} & \multirow[t]{2}{*}{$\begin{array}{l}\text { Std. Error } \\
\text { Difference }\end{array}$} & \multicolumn{2}{|c|}{$\begin{array}{l}95 \% \text { Confidence } \\
\text { Interval of the } \\
\text { Difference }\end{array}$} \\
\hline & & & & & & & & & Lower & Upper \\
\hline \multirow[t]{2}{*}{$\begin{array}{l}\mathrm{N} \text { Gain } \\
\text { Indikator } \\
1\end{array}$} & \begin{tabular}{|l} 
Equal \\
variances \\
assumed \\
\end{tabular} & ,833 &, 365 & 1,048 & 58 & ,299 &, 05700 &, 05437 &,- 05184 &, 16584 \\
\hline & $\begin{array}{l}\text { Equal } \\
\text { variances } \\
\text { not } \\
\text { assumed } \\
\end{array}$ & & & 1,048 & 57,962 & ,299 &, 05700 &, 05437 &,- 05184 & , 16584 \\
\hline \multirow[t]{2}{*}{$\begin{array}{l}\mathrm{N} \text { Gain } \\
\text { Indikator } \\
2\end{array}$} & \begin{tabular}{|l} 
Equal \\
variances \\
assumed \\
\end{tabular} & ,121 & ,729 & ,712 & 58 & ,479 &, 03800 &, 05336 &,- 06882 & , 14482 \\
\hline & $\begin{array}{l}\text { Equal } \\
\text { variances } \\
\text { not } \\
\text { assumed }\end{array}$ & & &, 712 & 57,993 & ,479 & ,03800 &, 05336 &,- 06882 & , 14482 \\
\hline \multirow[t]{2}{*}{$\begin{array}{l}\mathrm{N} \text { Gain } \\
\text { Indikator } \\
3\end{array}$} & \begin{tabular}{|l} 
Equal \\
variances \\
assumed \\
\end{tabular} & 1,528 & ,221 & 3,158 & 58 &, 003 &, 11700 &, 03705 &, 04284 & , 19116 \\
\hline & $\begin{array}{l}\text { Equal } \\
\text { variances } \\
\text { not } \\
\text { assumed }\end{array}$ & & & 3,518 & 55,422 &, 003 &, 11700 & ,03705 &, 04277 & , 19123 \\
\hline \multirow[t]{2}{*}{$\begin{array}{l}\mathrm{N} \text { Gain } \\
\text { Indikator } \\
4\end{array}$} & \begin{tabular}{|l|} 
Equal \\
variances \\
assumed \\
\end{tabular} & ,134 & ,716 & 3,129 & 58 &, 003 & , 14167 &, 04527 &, 05105 & ,23228 \\
\hline & $\begin{array}{l}\text { Equal } \\
\text { variances } \\
\text { not } \\
\text { assumed }\end{array}$ & & & 3,129 & $\begin{array}{r}56 \\
360\end{array}$ &, 003 & , 14167 &, 04527 &, 05105 & ,23234 \\
\hline \multirow[t]{2}{*}{$\begin{array}{l}\mathrm{N} \text { Gain } \\
\text { Indikator } \\
5\end{array}$} & \begin{tabular}{|l} 
Equal \\
variances \\
assumed \\
\end{tabular} & 2,404 & , 126 & 4,720 & 58 &, 000 & , 14500 &, 03072 & ,08346 & ,20650 \\
\hline & $\begin{array}{l}\text { Equal } \\
\text { variances } \\
\text { not } \\
\text { assumed }\end{array}$ & & & 4,720 & 56,238 &, 000 & , 14500 &, 03072 & ,08346 & 20650 \\
\hline
\end{tabular}

From Table 8 above, it can be seen that the significance value of indicator 1 is $0.299>0.05$ which concludes that there is no significant difference (real) then refers to the N-Gain score indicator 1 which shows the N-Gain score of Experiment Class A 0.726 is better than the N-Gain score for Experiment Class B of 0.669 but the results of the independent $\mathrm{T}$ Test in table 8 above conclude that there is no significant difference in increasing selfconfidence in the indicators of self-confidence in students' self-confidence that are taught with a metacognitive approach that gives the same changes as students. who are taught with a realistic mathematical approach.

In indicator 2 the significance value is $0.479>0.05$ which concludes that there is no significant difference (real) then refers to the N-Gain score indicator 2 which shows the N-Gain score for Experiment Class A of 0.691 is better than the $\mathrm{N}$-Gain score Experiment Class B is 0.654 but the results of the independent $\mathrm{T}$ Test in table 8 above conclude that there is no significant difference in the increase in self-confidence in the indicator of optimistic attitude of students who are taught with a metacognitive approach which also gives the same changes as students who are taught with a realistic mathematics approach 
In indicator 3 the significance value is $0.003<0.05$, concludes that there is a significant difference (real) then refers to the N-Gain score of indicator 3 which shows that the N-Gain score for Experiment Class A is 0.720 better than the N-Gain score for the Experiment Class B is 0.603, then the results of the independent $\mathrm{T}$ Test in table 8 above conclude that there is a significant difference in the increase in self-confidence in the indicators of the objective attitude of students who are taught with a metacognitive approach better than students who are taught with a realistic mathematics approach.

In indicator 4 the significance value is $0.003<0.05$ which concludes that there is a significant difference (real) then refers to the $\mathrm{N}$-Gain score of indicator 4 which shows that the $\mathrm{N}$-Gain score for Experiment Class $\mathrm{A}$ is 0.720 better than the N-Gain score for Class Experiment B is 0.578 and the results of the independent T Test in table 8 above conclude that there is a significant difference in the increase in mathematical reasoning abilities on the indicator of the responsible attitude of students who are taught with a metacognitive approach which gives a better improvement than students taught with a realistic mathematical approach.

In indicator 5 the significance value is $0.000<0.05$, giving the conclusion that there is a significant difference (real) then referring to the N-Gain score indicator 5 which shows the N-Gain score for Experiment Class A of 0.14 is better than the $\mathrm{N}$-Gain score Experiment Class B is 0.579 , so the results of the independent $\mathrm{T}$ Test in table 8 above conclude that there is a significant difference in increasing self-confidence in the indicators of rational and realistic attitudes of students who are taught with a metacognitive approach better than students taught with a realistic mathematics approach

Table 9. Summary of Differences in Self Confidence Improvement in Each Indicator

\begin{tabular}{|l|c|c|c|c|c|}
\hline \multirow{2}{*}{\multicolumn{1}{|c|}{ Class }} & \multicolumn{5}{c|}{ N-Gain Score Self Confidence } \\
\cline { 2 - 6 } & Indicator 1 & Indicator 2 & Indicator 3 & Indicator 4 & Indicator 5 \\
\hline Experiment A & 0,726 & 0,691 & 0,720 & 0,720 & 0,714 \\
\hline Experiment B & 0,669 & 0,654 & 0,603 & 0,578 & 0,579 \\
\hline Sig 2 tailed & 0,299 & 0,479 & 0,003 & 0,003 & 0,000 \\
\hline
\end{tabular}

Based on the research results, it shows that in general the increase in students' mathematical reasoning abilities and self-confidence of students who are taught with a metacognitive approach is higher than the increase in those taught with a realistic mathematics approach. However, indicators 3 and 4 make assumptions and construct evidence and use relationship patterns to analyze situations, or make analogies or generalizations, there is no significant difference in improvement between the two experimental classes. This shows that the metacognitive approach has the advantage of being used in improving mathematical reasoning abilities

Learning with a metacognitive approach is a learning design that refers to ways to increase awareness of students' thinking processes. Increased awareness of students 'thinking processes will have an impact on students' thinking activities to draw conclusions or thinking processes in order to make a new true statement based on statements whose truth has been proven or previously assumed. So that the metacognitive approach has more impact on students' mathematical reasoning abilities.

Although the higher metacognitive approach provided an increase in students' mathematical reasoning, the realistic mathematics approach also provided a significant increase in the pre-test and post-test scores. The difference in learning approaches that exist in the two classes, namely students who get learning with a metacognitive approach and students who get learning with a realistic mathematics approach, will cause differences in student learning outcomes in mathematical reasoning and student self-confidence.

\section{Conclusion}

The Based on the results of data analysis and discussion in this study, the following conclusions are stated:

1. There are differences in the increase in students' mathematical reasoning abilities with a metacognitive approach higher than the realistic mathematics approach. Based on the results of the analysis of the Independent $\mathrm{T}$ Test $\mathrm{N}-$ Gain Test, the significance value was obtained $=0.008$. Because of the sig level. smaller than 0.05 , so that $\mathrm{H}_{0}$ is rejected and $\mathrm{H}_{1}$ is accepted.

2. There is a difference in the increase in students' self confidence with the metacognitive approach which is higher than the realistic mathematics approach. Based on the results of the analysis of the Independent $\mathrm{T}$ Test $\mathrm{N}$-Gain Test, the significance value was obtained $=0.000$. Because of the sig level. smaller than 0.05 , so that $\mathrm{H}_{0}$ is rejected and $\mathrm{H}_{1}$ is accepted.

3. There is a significant difference in the increase in mathematical reasoning abilities in indicator 1 draws logical conclusions, indicator 2 provides an explanation of models, facts, properties and relationships or patterns that students taught with a metacognitive approach are higher than students taught with a realistic mathematical approach.

4. There is no significant difference in the increase in mathematical reasoning abilities in indicator 3 making assumptions and compiling proof of indicator 4 using relationship patterns to analyze situations, or making analogies or generalizations between students being taught and the metacognitive approach with students taught with a realistic mathematical approach. 
5. There is no significant difference in the increase in mathematical reasoning abilities on indicator 1 of selfconfidence and indicator 2 of an optimistic attitude between students who are taught with a metacognitive approach and students who are taught with a realistic mathematics approach.

6. There is a significant difference in the increase in self-confidence in indicators of 3 objective attitudes, 4 indicators of responsible attitudes, and indicators of 5 rational and realistic attitudes of students who are taught with a metacognitive approach are better than students taught with a realistic mathematics approach.

\section{References}

Amin. A.K. (2017). Implementasi Pembelajaran Matematika Realistik Dengan Model Kooperatif Pada Materi Persamaan Linear Satu Variabel di MTs Darul Ulum Kelas VII. (Online). Artikel https://www.researchgate.net/publication/320237765.

Fitri, S., Syahputra, E., \& Syahputra, H. (2019). Blended Learning Rotation Model of Cognitive Conflict Strategy to Improve Mathematical Resilience in High School Students. International Journal of Scientific \& Technology Research, 1 (1).

Fitri, S., \& Zahari, C.L. (2019). The implementation of blended learning to improve understanding of mathematics. The Sixth Seminar Nasional Pendidikan Matematika Universitas Ahmad Dahlan 2018: IOP Conf. Series: Journal of Physics: Conf. Series 1188 (2019) 012109, 2018, doi:10.1088/1742-6596/1188/1/012109.

Hernawati. F. (2016). Pengembangan Perangkat Pembelajaran Matematika Dengan Pendekatan Pmri Berorientasi Pada Kemampuan Representasi Matematis. (Online), .3 (1).

Hutauruk. A.J.B. (2016). Pendekatan Metakognitif dalam Pembelajaran Matematika. Prosiding. (Online). ISBN 978-602-71252-1-6.

Lubis. C. M \& Surya. E.(2016). Analisis Keefektifan Belajar Matematika Melalui Pendekatan Stop Think Do Pada Siswa MTs. Budi Agung Tahun Pelajaran 2013/2014. Jurnal Pendidikan Matematika. (Online), .4 (3).

Martyanti. A. (2013). Membangun Self-Cofidence Siswa dalam Pembelajaran Matematika Dengan Pendekatan Problem Solving. Prosiding. (Online), ISBN : 978 - $979-16353-9-4$.

Mustamin. H. (2017). Pembelajaran Matematika dengan Pendekatan Realistik. Jurnal Lentera Pendidikan. (Online), 20 (2).

Nasution. I. A dan Surya. E. (2017). Analisis Pendekatan Metakognitif Terhadap Kemampuan Penalaran Matematika Siswa SMP. (Online), Artikel https://www.researchgate.net/publication/320726335.

Nurkholifah. S, Toheri \& Winarso. W. (2018). Hubungan antara Self Confidence dengan Kemampuan Berpikir Kritis Siswa dalam Pembelajaran Matematika. Jurnal Edumatica. (Online), .8 (1).

Pane. N, Syahputa. E \& Mulyono. (2018). Improving the Ability of Creative Thinking Mathematically and SelfConfidence Student through Application Model Eliciting Activities (MEAs) Review from Student Gender. American Journal of Educational Research. (Online), 6 (4).

Purba. G.I.D, Surya. E, Manullang. M \& Asmin. (2018). The Effect of Students' Worksheet in the Model of Discovery Learning Against the Students' Ability of Reasoning and Mathematical Communication in the Faculty of Mathematics and Natural Science of State University of Medan. Jurnal International Journal of Sciences: Basic and Applied Research (IJSBAR). (Online), 37 (3).

Rizqi. N.R \& Surya. E. (2017). An Analysis of Students' Mathematical Reasoning Ability in VIII Grade of Sabilina Tembung Junior High School. Jurnal IJARIIE. (Online), 3 (2).

Surya. E, Putri. F. A \& Mukhtar. (2017). Improving Mathematical Problem-Solving Ability and Self-Confidence of High School Students Through Contextual Learning Model. Journal on Mathematics Education. (Online), $8(1)$. 